\title{
Maternal solubility test and high performance liquid chromatography of newborns in combination as a better neonatal screening protocol for sickle cell disease
}

\author{
Phuljhele $\mathbf{S}^{1}$, Ramnani $\mathrm{K}^{2}$, Hiwale $\mathrm{S}^{2}$, Ramteke $\mathrm{PP}^{3}$ \\ ${ }^{1}$ Dr. Sharja Phuljhele, Professor, Department of Paediatrics, ${ }^{2}$ Dr. K. Ramnani, Assistant Professor, Department of \\ Pediatrics, ${ }^{2}$ Dr. S. Hiwale, Associate Professor, Department of Biochemistry, ${ }^{3}$ Dr. Priyanka Pruthviraj Ramteke, \\ Postgraduate fellow, Department of Pediatrics Pt. J. N. M. Medical Raipur, Chhattisgarh, India.
}

Address for Correspondence: Dr. Sharja Phuljhele,Email - sharjaphuljhele@ gmail.com

\begin{abstract}
Introduction: The incidence and prevalence of sickle cell disease in India is high and they are major health problem in India. Neonatal detection and prophylactic management can reduce morbidity and mortality in childhood. A study is therefore planned for analyzing maternal solubility test and HPLC of newborn as effective screening protocol. Material and Method: The infants born of solubility positive mothers were taken for hemoglobin analysis using Biorad Hemoglobin variant by high performance liquid chromatography (HPLC) at birth and the test was repeated at six months of age. Data were analyzed using appropriate statistical method. Results: A total of 100 mothers were positive on solubility test, their infants underwent $\mathrm{Hb}$ analysis by high performance liquid chromatography. 74 infants shows normal hemoglobin variants while 19 were heterozygous for Hbs (sickle cell trait) and 7 babies were homozygous for HbS at birth. On follow up at 6 month of age cases were reanalyzed by HPLC, 12 cases were lost in follow up, 7 cases who were heterozygous for sickle cell turned out to be homozygous for sickle cell, and of those with normal reports 7 cases were homozygous. Conclusion: Maternal solubility test and HPLC of newborn at birth is good screening protocol for sickle cell anemia
\end{abstract}

Keywords: High Performance Liquid Chromatography, Sickle Cell Disease, Solubility Test.

\section{Introduction}

Sickle cell disease is an autosomal recessive genetically transmitted hemoglobinopathy responsible for considerable morbidity and mortality [1]. This hereditary disorder is due to defective hemoglobin structure. Sickle cell disorder is caused by a point mutation at sixth position in beta globin chain, Valine substituting Glutamic acid, due to which in deoxygenated state the shape of erythrocytes change to sickle shape and also the fragility of cell membrane increases [2].

The very first description of sickle cell disease was provided by Dr. James Harrick in 1910 when he was studying blood cells under light microscopy of $20 \mathrm{yr}$ old dental student who came with complaint of fever and

Manuscript received $24^{\text {th }}$ April 2016

Reviewed: $4^{\text {th }}$ May 2016

Author Corrected: $13^{\text {th }}$ May 2016

Accepted for Publication $27^{\text {th }}$ May 2016 anemia and he noted "large number of thin sickleshaped and cresent shaped" red blood cells [3]. For many years, sickle cell gene has been considered as a disease confined to people of African ancestry although the gene was described in southern India in person with African origin, as early as 1952 [4]. Each year approximately 300000 children are born with sickle cell anemia or of its variant and the worldwide affected birth prevalence is estimated at 2.55 per 1000 [5]. In recent years its incidence has increased dramatically also in Europe and north America because of high rate of migration of people from endemic area [6]. It represents one of the major health problems in Central India and constitutes the most common genetic disorder in some communities.

In India, the carrier rate of $\mathrm{HbS}$ mutation varies among states, communities and ethnic groups with an average 
prevalence of $4.3 \%(0-44 \%)$. It is predominantly found in Vidarbha (North Maharashtra), Chhattisgarh, Madhya Pradesh, Orissa, Gujarat and some areas of Andhra Pradesh, Tamilnadu, Kerala, and Karnataka. Previously it was believed that sickle cell gene in India was found predominantly in tribal communities. However later studies have shown an equally high prevalence even in non tribal communities from central and eastern India [7].

Sickle Cell Belt of Chhattisgarh include Raipur, Durg, Rajnadgaon, Mahasamaud, Dhamtari, kanker, Baster, Dantewada, Narayanpur, Bijapur, Bilaspur, Janjhgir, Raigarh, korba, Jashpur, Sarguja, kawardha [8,9].

According to findings of an ongoing project at Pt. Jawaharlal Nehru Medical College, around $10 \%$ of state's population has prevalence of sickle cell anemia. The state population, according to 2011 census stands at 2.56 crore, which means that around 25 lakh are affected from this disorder [9].

Newborn screening for sickle cell disease began in United States in the early 1970s. In the US, newborn screening has evolved from isolated testing for metabolic disorders to universal screening for more than 30 genetic disorders, including sickle cell disease and other hemoglobinopathies. Now, sickle cell disease has become part of National Newborn screening programs for genetic disorders in several countries.

However, in India there are no such programs at present. Early diagnosis immediately after birth by newborn screening program followed by placement in comprehensive care system has improved the life expectancy of person with sickle cell disease. The most commonly used initial screening methods for detection of sickle cell anemia include high performance liquid chromatography (HPLC), isoelectric focusing or cellulose acetate electrophoresis [10]. Since percentage of fetal hemoglobin [HBF] high and sickle cell hemoglobin is very low in early neonatal period [11], neonatal sickle cell short screening program was done using HPLC rather than going for hemoglobin electrophoresis. And since there are no programs at state or national level on neonatal screening for sickle cell disease in India, an attempt has been made to look at neonatal screening of sickle hemoglobin in high risk communities.

Our study aims at early diagnosis of sickle cell disease at newborn period by HPLC (High Profile Liquid
Chromatography) so that that the affected newborns can be identified and placed in comprehensive health care system.

\section{Material and Method}

Longitudinal Prospective Cohort study planned for a period of one and half years from $1^{\text {st }}$ February 2014 to $30^{\text {th }}$ September 2015 in the Department of Pediatrics in collaboration with department of Biochemistry, Pt. Jawaharlal Nehru Memorial Medical College and Dr. B. R. Ambedkar Memorial Hospital Raipur.

According to sensitivity of $95 \%$ and specificity $99 \%$, prevalence of $10 \%$ for 0.1 precision sample size was calculated as 100 solubility test positive mothers.

All mothers underwent a solubility test either before delivery or within 48 hours after delivery of a live baby. Mothers with positive solubility test result were further evaluated with a detailed clinical examination, after taking proper consent from family.

A venous blood sample from the baby (around $0.5 \mathrm{ml}$ ) was collected in an EDTA (Ethylenediaminetetraacetic acid) tube during the first $72 \mathrm{hrs}$ of life. Hemoglobin analysis was done using cation exchange HIGH PERFORMANCE liquid chromatography variant Hemoglobin Testing System using the sickle cell short program (Bio-Rad Laboratories, Hercules, CA, USA). Confirmatory testing done at 6 month on follow up by repeat HPLC. Data was collected on proforma with complete demographic detail

- History of transfusion in father

- History of transfusion in mother and other family members. On follow up parents were called at hospital for repeat HPLC of neonate at 6 month.

All the neonates grouped according to HPLC positive and negative at birth

Depending on the number of neonates diagnosed as sickle cell disease at 6 months of age $\&$ the sensitivity and specificity has been calculated

- Sensitivity - True positive/ true positive + false negative $\mathrm{x} 100$

- Specificity - True negative/ false positive + true negative $\mathrm{x} 100$

- Positive predictive value - true positive / true positive + false positive $\mathrm{x} 100$

- Negative predictive value - true negative / true negative + false negative $\times 100$ 


\section{Results}

This study is on newborn screening for sickle cell disease by high performance liquid chromatography done from period of $1^{\text {st }}$ February 2014 to $30^{\text {th }}$ of September 2015 in Pt. Jawaharlal Nehru Memorial Medical College and Dr. B. R. Ambedkar Memorial Hospital Raipur. Our study started with sample size of 100 solubility positive mothers, newborns of these mothers were screened by high performance liquid chromatography at birth and these results were confirmed by repeat HPLC at 6 month. Out of 100 newborns screened 59 were males and 41 were females, 7 were less than $2 \mathrm{~kg}$ and 93 were between 2 to $2.5 \mathrm{~kg}$.

Table 1: Results of high performance liquid chromatography at birth.

\begin{tabular}{|l|l|l|}
\hline Hb phenotype at birth & No of newborns & Percent \\
\hline FA & 74 & 74.0 \\
\hline FAS & 19 & 19.0 \\
\hline FS & 7 & 7.0 \\
\hline Total & $\mathbf{1 0 0}$ & $\mathbf{1 0 0 . 0}$ \\
\hline
\end{tabular}

74 out of 100 newborns shows normal hemoglobin variant, 19 shows sickle cell trait ( FAS ) and 7 shows sickle cell disease (FS).

Table 2: Results of high performance liquid chromatography at 6 month.

\begin{tabular}{|l|l|l|}
\hline Hb phenotype $\mathbf{- 6} \mathbf{~ m}$ & No of newborns & Percent \\
\hline AA & 57 & 57.0 \\
\hline AS & 10 & 10.0 \\
\hline SS & 21 & 21.0 \\
\hline Lost & 12 & 12.0 \\
\hline Total & 100 & 100.0 \\
\hline
\end{tabular}

Out of 100 infants 57 shows normal hemoglobin variant; 10 sickle cell trait (AS ); 21 have sickle cell disease (SS) and 12 cases lost during follow up .

Table-3: Correlation of HPLC results at birth and at 6 month.

\begin{tabular}{|l|l|l|l|l|l|}
\hline \multirow{2}{*}{ Hb phenotype at birth } & \multicolumn{4}{|l|}{ Hb phenotype - $\mathbf{~ m}$} & \multirow{2}{*}{ Total } \\
\cline { 2 - 6 } & AA & AS & SS & Lost & 74 \\
\hline FA & 57 & 0 & 7 & 10 & 19 \\
\hline FAS & 0 & 10 & 7 & 2 & 7 \\
\hline FS & 0 & 0 & 7 & 0 & 100 \\
\hline Total & 57 & 10 & 21 & 12 & 12 \\
\hline
\end{tabular}

At birth 74 newborns had normal hemoglobin variant (FA) out of which at 6 month only 57 came out to be normal, 7 shows (SS) sickle cell disease pattern and 10 lost in follow up. At birth 19 cases showed (FAS) hemoglobin variant out of which at 6 month only 10 cases came out to be (AS) sickle cell trait positive 2 cases lost in follow up and 7 cases turned out to be SS positive. At birth 7 cases had (FS) hemoglobin variant that remain to be SS (sickle cell disease) positive at 6 month.

Table 4: Community distribution of sickle cell newborns

\begin{tabular}{|l|l|l|l|l|l|}
\hline \multirow{2}{*}{ Communities } & \multicolumn{3}{|l|}{ Sickle cell disease } & \multirow{2}{*}{ Total } \\
\cline { 2 - 6 } & Absent & $\mathbf{\%}$ & Present & $\mathbf{\%}$ & \\
\hline SC & 19 & 65.5 & 10 & 34.5 & 29 \\
\hline ST & 20 & 83.3 & 4 & 16.7 & 24 \\
\hline OBC & 14 & 45.2 & 17 & 54.8 & 31 \\
\hline OTHERS & 4 & 100.0 & 0 & 0.0 & 4 \\
\hline Total & $\mathbf{5 7}$ & $\mathbf{6 4 . 8}$ & $\mathbf{3 1}$ & $\mathbf{3 5 . 2}$ & $\mathbf{8 8}$ \\
\hline
\end{tabular}


$\mathrm{P}$ value 0.004, significantly more sickle cell disease in Other Backward Classes as compared to Scheduled cast and Scheduled tribe

Table 4 Shows total 31 newborns have sickle cell anemia among 100 newborns (10 AS positive,2 1 SS positive) out of which 17 belongs to Other Backward Community category with highest prevalence in sahu and kurmi community, 10 from Scheduled caste and 4 belongs to Scheduled tribe.

Table 5: Calculation of sensitivity and specificity of test.

\begin{tabular}{|l|l|l|l|l|}
\hline & & Disease & \\
\hline & & \multirow{2}{*}{$\begin{array}{l}\text { Present } \\
(\text { SS/AS })\end{array}$} & $\begin{array}{l}\text { Absent } \\
(\text { AA })\end{array}$ & Total \\
\cline { 3 - 5 } & & & 0 & 24 \\
\hline \multirow{3}{*}{ HPLC Test Results } & - & 7 & 57 & 64 \\
\hline Total & & $\mathbf{3 1}$ & $\mathbf{5 7}$ & $\mathbf{8 8}$ \\
\hline
\end{tabular}

Present study has $77 \%$ sensitivity means $77 \%$ of newborns screened by the test are true positive. It has $100 \%$ specificity as having no false positive cases and $100 \%$ of newborns screened by test are true negative. It have $100 \%$ positive predictive value and $89 \%$ negative predictive.

\section{Discussion}

The present study was undertaken to prove that High performance liquid chromatography of newborns of mothers who were sickles as per the solubility test is a good screening tool for diagnosis of sickle cell disease at birth.

At birth among 100 newborns screened 74 had normal hemoglobin variant (FA), 19\% (FAS) and 7\% were having (FS) pattern while none have undistinguished bands. On follow up, 12 cases lost and 14 cases turned out to be sickle cell disease which were initially labeled as having normal hemoglobin variant (FA) in 7 cases and (FAS) in 7 cases. So on follow up we got sickle cell trait (AS) in $10 \%$ cases and sickle cell disease (SS) in $21 \%$ cases. D. L. Jain et al 2012 using capillary blood analysis by HPLC of newborns to sickle cell anemic mothers, found sickle cell disease (FS) in $7 \%$ cases but $45 \%$ cases have sickle cell trait (FAS) which is higher than present study [10].

Panigrahi et al 2012 [12] found, 94\% had normal phenotype (FA), sickle cell disease (FS) in 3 cases $(0.2 \%)$ and sickle cell trait (FAS) in $68(5.8 \%)$. This study was conducted in the same institute as the present study.

The results reveal a slightly lesser incidence as compared to our study. The lesser incidence is because of mass screening irrespective of sickling status of parent. On reinvestigation of 10 infants, 2 had sickle cell disease, 1 had sickle cell trait and 7 infants were normal. The study also had 2 false negative cases in which one was HbSS which was earlier reported as FAS and other was sickle beta thalassemia trait which was reported as FS earlier as compared to our study which showed 7 false negative. Rabitaille et al 2006 [13] had found $10.5 \%$ of sickle cell trait and $0.4 \%$ sickle cell disease in their mass neonatal screening done by HPLC method in Quebec.

On follow up, there were 3 false negative cases, 1 $\mathrm{HbS}+$ Beta thalassemia and $2 \mathrm{HbSS}$ which were reported earlier to be FA, FAS, FAS respectively. In the study done by Adjaye et al 1989 [14] using cord blood analysis of newborn to sickle cell anemia mothers done by Hemoglobin electrophoresis method, they found $5.5 \%$ cases of sickle cell disease. Twelve neonates had $\mathrm{F}+$ indistinct band in initial screening, on their follow up after 6 month, 4 had sickle cell trait.

Another study conducted at Florida by Renee V. G. et al 1983 [15] using hemoblobin electrophoresis had found an incidence of sickle cell disease in $0.5 \%$ and carrier frequency of $8.3 \%$. In our study among 100 solubility positive mothers, $35 \%$ belongs to Other Backward Classes, 32\% Scheduled Caste, 28\% Scheduled Tribe and $5 \%$ to others and their newborns who were screened out to be positive for sickle cell anemia $17 \%$ belongs to 
Other Backward Classes with highest incidence from Sahu, Kurmi community, 10\% Scheduled Caste and $4 \%$ to Scheduled Tribe. P.K. Patra et al 2010 [16] found although prevalence is high for Scheduled Caste and Scheduled Tribe community it is highest for Kurmi $(55 \%)$ and Teli $(53 \%)$ caste which belong to Other Backward Class. D.L Jain et al 2012 [10] found prevalence of sickle cell gene is highest in mothers belonging to Scheduled Caste $22.5 \%$ followed by Other Backward Class 22\% although prevalence of sickle cell carrier is similar in Scheduled Caste and Other Backward Class.

Our study able to screen $19 \%$ of sickle cell trait and $7 \%$ of sickle cell disease newborns at birth by HPLC, so total $26 \%$ of sickle cell anemic infants are screened by our study at birth as compared to study done by Panigrahi et al 2012 [12] which found 5.8\% sickle cell trait and $0.2 \%$ sickle cell disease newborns at birth.

This shows yield of our study is higher than this study, this is because of our specific screening which taken into account mother sickling status.

Sensitivity of present neonatal screening protocol for sickle cell anemia is $77 \%$, specificity and positive predictive value is $100 \%$ with negative predictive value is $89 \%$. This shows present neonatal screening protocol is better for screening of sickle cell anemia.

\section{Conclusion}

The prevalence of sickle cell anemia in Chhattisgarh is $10 \%$, hence there is need to implement neonatal screening program for sickle cell disease in Chhattisgarh. Specificity of HPLC as a newborn screening test is good, this fact was previously known but when we add solubility test of parents, yield of screening tool become better. So, we recommend this approach until universal neonatal screening programs are implemented over large scale.

Funding: Nil, Conflict of interest: None initiated. Permission from IRB: Yes

\section{Bibiliography}

1. James V.Neel. The inheritance of sickle cell anemia. Science1949; Volume 110: 64.

2. Ingram VM. A specific chemical difference between the globin of normal human and sickle cell anemia. Hb Nature 1956; 178: 792-794.
3. Dr. James B.Herrick. Peculiar elongated and sickled shaped RBC in peripheral smear of American Negros. Arch Int Med 1910; 6:57:517-521.

4. Lehman and Cutbush. Sickle cell trait in southern India. M Brit Med.J. 1952 Feb; 1: 404.

5. Bernardette Modell, Matthew Darlison. Global epidemiology of hemoglobin disorders and derived service indicators. Bull World Health Organ June 2008 Vol. 86n.6Geneva.

6. Elisa Ballardini, Anna Tarocco, Maria Marsella, Roberto Bernerdoni, Gianni Carandina, Claudia Melandri, et al. Univeral neonatal screening for sickle cell disease in Ferrara, Italy. Blood Tranfus. 2013 Apr; 11(2): 245-249.

7. Agrawal MB. The burden of hemoglobinopathies in India- time to wake up. J Assoc Physicians India2005; 53: 1017-1078.

8. Pradip K. Patra ,Virander S. Chauhan et al. screening for sickle cell gene in Chhattisgarh state, India; an approach to major publichealth problem . j. community Genet 2011 Sept; 2(3): 147-151.doi 10. 1007/s 12687011-0050-4.

9. Sapna Thakur, Ravindra Sharma and Sharda Nandan Raw. Incidence of Thalassemia and Sickle Cell Disease in Chhattisgarh, Central India: Using Hardy-Weinberg Equations. J Mol Genet Med 2015; 9(1): 1-5.

10. Dipty L. Jain, Vijaya Sarathi, Dipty Upadhye, Rohini Gulhane, Anita H. Nadkarni, Kanjaksha Ghosh, and Roshan B. Colah. Newborn Screening Shows High Incidence of Sickle Cell Anemia in Central India. Hemoglobin 2012; 36(4) : 316-322.

11. J.Watson. A study of sickling of young erythrocytes in sickle cell anemia. Blood 1948; 3: 465-469.

12. Sumanta Panigrahi, Pradeep Kumar Patra, Prafulla Kumar Khodiar. Neonatal Screening of Sickle Cell Anemia: A Preliminary Report. Indian J Pediatr June 2012 ; 79(6): 747-750.

13. Nancy Robitaille,Edgard E Delvin, Heather A Hume. Newborn screening for sickle cell disease : A 1983-2003 Quebec experience. Journal of pediatric child health 2006 Apr; 11(4): 223- 227. 
14. N Adjaye, B J Bain, P Steer et al (1983-1986) . Prediction and diagnosis of sickling disorder in neonates at London. Archives of disease in childhood 1989; 64: 39-43.

15. Renee V.Gardner, Alan Keitt. University of Florida sickle cell screening program for neonates : design and results. J National Med Asso. 1988 mar; 80(3): 2753.
16. Pradeep K. Patra, Tripathi sumit, Khodiar Prafulla, Sablania Pravin ,Keshari JR, Dalla A.R., Epidemiology of sickle cell disease in Chattisgarh. Indian Journal of Public Health Reaserch and Development 2010; 1(2): 64-68.

\section{How to cite this article?}

Phuljhele S, Ramnani K, Hiwale S, Ramteke PP.Maternal solubility test and high performance liquid chromatography of newborns in combination as a better neonatal screening protocol for sickle cell disease. Int J Med Res Rev 2016;4 (6):999-1004.doi: 10.17511/ijmrr.2016.i06.23. 